\title{
COMPARATIVE STUDY OF THE FECUNDITY AND FERTILITY OF Biomphalaria glabrata (Say, 1818) AND Biomphalaria straminea (Dunker, 1848) IN A LABORATORY THROUGH SELF-FERTILIZATION AND CROSS-FERTILIZATION
}

\author{
Marta Julia F.S. COSTA(1), Carlos Eduardo GRAULT(1) \& Ulisses E.C. CONFALONIERI(2)
}

\begin{abstract}
SUMMARY
The aim of this study was to compare the fecundity and fertility of B. glabrata and B. straminea by cross- and self-fertilization. To attain this objective, laboratory-raised strains of B. glabrata and B. straminea were used. The former originated from natural breeding grounds in the municipality Paulista, state of Pernambuco, Brazil. The latter originated from irrigation ditches in the municipality of Petrolândia, in the same state. Snail populations of B. glabrata and B. straminea were maintained for 240 days in laboratory. Their fecundity was evaluated by noting the number of egg-masses, eggs and eggs per mass. Their fertility was evaluated by the number of viable eggs and the hatching rate.

B. straminea was markedly more fecund than B. glabrata through cross- and self-fertilization, namely: greater egg-mass; higher egg production and more eggs per mass. Regarding fertility, there seemed to be no preferential period for occlusion to occur or a trend in the rhythm of producing viable eggs.
\end{abstract}

KEYWORDS: Biomphalaria straminea; Biomphalaria glabrata; Cross-fertilization; Self-fertilization.

\section{INTRODUCTION}

Studies under semi-natural and field conditions have revealed the competitive superiority of $B$. straminea over $B$. glabrata $^{3,4,5,6,8,9}$. Among the factors involved, in addition to low susceptibility to infection by $S$. mansoni and greater resistance to desiccation, better dispersal capacity and higher vagility were noted for the former species ${ }^{6,7,14,27}$. However, the few existing studies comparing the reproducibility of these two species invariably attribute a higher fecundity rate to $B$. glabrata $^{1,2,15,19}$. More recent observations of the fecundity of $B$. straminea compared to $B$. glabrata found a higher fecundity rate in $B$. stramine $a^{26}$.

Studies comparing the fecundity of B. glabrata and B. straminea are rare, with that by PENIDO et al. ${ }^{22}$ being particularly noteworthy. There is also a dearth of studies of self-fertilization, and those that exist mostly cover B. glabrata, attributing preference to self-fertilization ${ }^{11,23}$. Other authors attribute the preference of this species to crossreproduction ${ }^{10,20,25}$. Despite studies indicating the competitive superiority of B. straminea over B. glabrata, little is known about the factors favoring the species. Among these factors, reproduction is one of the most important elements in the dynamics of this process. Consequently, the main purpose of this work is to compare the fecundity and fertility of $B$. glabrata and B. straminea under laboratory conditions, based on selffertilization and cross-fertilization.

\section{MATERIAL AND METHODS}

The study was carried out comparing two snail species, $B$. glabrata from natural breeding places in Paulista and $B$. straminea from irrigation ditches in Petrolândia, both rural municipalities in the state of Pernambuco in Northeast Brazil.

Thirty adult snails belonging to each species were placed in separate aquariums, each containing ten liters of water, and were left for 48 hours to lay the egg-masses. After this period, the adult snails were removed and the egg-masses in the aquariums were left for the eggs to hatch. After 15 days, 30 young snails were separated of each species and placed in smaller aquariums or beakers as follows:

30 snails (B. glabrata) - 20 in Aquarium 1 and 10 in 10 individual beakers; 30 snails (B. straminea) - 20 in Aquarium 2 and 10 in 10 individual beakers. Each aquarium and beaker contained 2 and 0.2 liters of water respectively, in addition to a layer of clay blended with calcium carbonate in proportions of 10:1 and 5:2 respectively, according to PARAENSE \& CORRÊA ${ }^{21}$.

In order to check fecundity, the number of eggs per egg-mass, eggs per snail and egg-masses per snail were counted on a weekly basis. Fresh lettuce was given as food. The fertility of the eggs was assessed through the snail hatch rate and the percentage of fertile eggs. Variance analysis

(1) Laboratório de Esquistossomose, Departamento de Ciências Biológicas, ENSP/FIOCRUZ, Rio de Janeiro, RJ, Brasil

(2) Programa de Mudanças Ambientais Globais e Saúde, Departamento de Ciências Biológicas, Escola Nacional de Saúde Pública, FIOCRUZ, Rio de Janeiro, RJ, Brazil

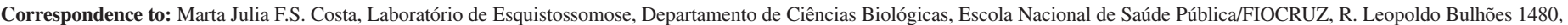

21041-210 Rio de Janeiro, RJ, Brasil. E-mail: mjfsc@ensp.fiocruz.br 


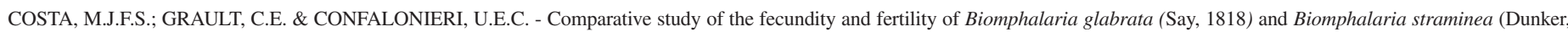
1848) in a laboratory through self-fertilization and cross-fertilization. Rev. Inst. Med. trop. S. Paulo, 46(3):157-163, 2004.

and the Student " $t$ " test were applied to compare fecundity, while the Z Coefficient was used to compare fertility through two proportions between the species and different age groups ${ }^{13}$.

\section{RESULTS}

\section{FECUNDITY}

Comparison of the number of egg-masses, eggs per snail and eggs per mass of B. glabrata and B. straminea raised in groups and individually: Table 1 gives the findings for the average of egg-masses and eggs per snail for two species raised in group. An average of 2.8 egg-masses per snail and 54.3 eggs per snail was obtained for B. glabrata, while $B$. straminea presented an average of 3.8 egg-masses per snail and 71.7 eggs per snail. The comparison of these two species indicates a significant difference $(\mathrm{p}<0.05)$ in almost all age groups, with an exception of the 206 - 221 day group for egg-mass capsules per snail.

When the species were raised individually, an average of 1.0 eggmass per snail and 8.1 eggs per snail was observed for B. glabrata, while $B$. straminea presented an average of 4.1 egg-masses per snail and 64.4 eggs per snail. The comparison between the averages for the number of egg-masses and eggs per snail in both species showed a significant difference $(\mathrm{p}<0.05)$ in almost all age groups, with $B$. straminea superior to B. glabrata. (Table 1)

Table 1

Number of egg-masses per snail and eggs per snail (mean) laid by Biomphalaria glabrata and Biomphalaria straminea raised in groups and individually, by age group

\begin{tabular}{|c|c|c|c|c|c|c|c|c|}
\hline \multirow[t]{2}{*}{$\begin{array}{l}\text { Age group } \\
\text { (days) }\end{array}$} & \multicolumn{2}{|c|}{$\begin{array}{c}\text { Egg-masses/snail } \\
\text { B. glabrata }\end{array}$} & \multicolumn{2}{|c|}{$\begin{array}{l}\text { Egg-masses/snail } \\
\text { B. straminea }\end{array}$} & \multicolumn{2}{|c|}{$\begin{array}{l}\text { Eggs/snail } \\
\text { B. glabrata }\end{array}$} & \multicolumn{2}{|c|}{$\begin{array}{l}\text { Eggs/snail } \\
\text { B. straminea }\end{array}$} \\
\hline & Group & Individual & Group & Individual & Group & Individual & Group & Individual \\
\hline $0-83$ & 0.0 & 0.0 & 0.0 & 0.0 & 0.0 & 0.0 & 0.0 & 0.0 \\
\hline $84-98$ & 0.0 & 0.0 & 0.4 & 0.8 & 0.0 & 0.0 & 2.9 & 2.9 \\
\hline $99-113$ & 0.7 & 0.4 & 1.5 & 2.1 & 7.5 & 3.0 & 18.5 & 30.0 \\
\hline $114-129$ & 1.4 & 3.3 & 2.8 & 5.4 & 21.4 & 36.0 & 38.2 & 88.4 \\
\hline $130-144$ & 3.7 & 1.3 & 2.0 & 7.9 & 60.4 & 9.1 & 113.0 & 126.8 \\
\hline $145-159$ & 4.3 & 2.0 & 5.3 & 6.2 & 62.4 & 18.0 & 98.6 & 94.9 \\
\hline $160-174$ & 5.5 & 2.4 & 12.3 & 8.2 & 87.0 & 18.2 & 243.7 & 155.3 \\
\hline $175-190$ & 2.6 & 1.2 & 5.8 & 6.4 & 48.6 & 5.0 & 102.4 & 109.8 \\
\hline $191-205$ & 4.2 & 0.0 & 10.6 & 3.3 & 77.0 & 0.0 & 140.6 & 37.8 \\
\hline $206-221$ & 3.3 & 0.5 & 2.4 & 2.2 & 71.6 & 1.5 & 46.0 & 13.1 \\
\hline $222-236$ & 5.8 & 1.0 & 3.5 & 3.5 & 162.0 & 3.0 & 57.5 & 71.4 \\
\hline $237-240$ & 3.1 & 1.0 & 0.0 & 4.2 & 54.8 & 4.1 & 0.0 & 43.4 \\
\hline Overall means & 2.8 & 1.0 & 3.8 & 4.1 & 54.3 & 8.1 & 71.7 & 64.4 \\
\hline
\end{tabular}

\begin{tabular}{|c|c|c|c|c|c|c|c|c|}
\hline $\begin{array}{l}\text { Age group } \\
\text { (days) }\end{array}$ & $\begin{array}{c}\text { Egg-masses/ } \\
\text { snail } \\
\text { Test "t" } \\
\text { B. glabrata X } \\
\text { B. straminea } \\
\text { (Group) }\end{array}$ & $\begin{array}{c}\text { Eggs/ } \\
\text { snail } \\
\text { Test "t" } \\
\text { B. glabrata X } \\
\text { B. straminea } \\
\text { (Group) }\end{array}$ & $\begin{array}{c}\text { Egg-masses/ } \\
\text { snail } \\
\text { Test "t" } \\
\text { B. glabrata X } \\
\text { B. straminea } \\
\text { (Individual) }\end{array}$ & $\begin{array}{c}\text { Eggs/ } \\
\text { snail } \\
\text { Test "t" } \\
\text { B. glabrata X } \\
\text { B. straminea } \\
\text { (Individual) }\end{array}$ & $\begin{array}{c}\text { Egg-masses/ } \\
\text { snail } \\
\text { Test “t” } \\
\text { B. glabrata } \\
\text { Group X } \\
\text { Individual }\end{array}$ & $\begin{array}{c}\text { Eggs/ } \\
\text { snail } \\
\text { Test “t” } \\
\text { B. glabrata } \\
\text { Group X } \\
\text { Individual }\end{array}$ & $\begin{array}{c}\text { Egg-masses/ } \\
\text { snail } \\
\text { Test "t" } \\
\text { B. straminea } \\
\text { Group X } \\
\text { Individual }\end{array}$ & $\begin{array}{c}\text { Eggs/ } \\
\text { snail } \\
\text { Test "t" } \\
\text { B. straminea } \\
\text { Group X } \\
\text { Individual }\end{array}$ \\
\hline $0-83$ & - & - & - & - & - & - & - & - \\
\hline $84-98$ & $-2.83 *$ & $7.61 *$ & $2.83 *$ & $5.38 *$ & - & - & -1.42 & 0.0 \\
\hline $99-113$ & $-2.36^{*}$ & $-9.59 *$ & $3.40 *$ & $14.86^{*}$ & 1.14 & $4.78^{*}$ & -1.08 & $-6.28 *$ \\
\hline $114-129$ & $-3.05^{*}$ & $-9.76 *$ & $2.25 *$ & $14.86^{*}$ & $-3.44 *$ & $-7.36 *$ & $-3.50 *$ & $-17.46^{*}$ \\
\hline $130-144$ & $-3.22 *$ & $-17.72 *$ & $6.88 *$ & $31.93 *$ & $3.69 *$ & $20.22 *$ & -1.90 & $-3.27 *$ \\
\hline $145-159$ & $-1.34 *$ & $-12.33^{*}$ & $4.64 *$ & $22.89 *$ & $3.54 *$ & $16.51 *$ & -0.92 & 0.97 \\
\hline $160-174$ & $-6.89 *$ & $-37.03 *$ & $5.55 *$ & $32.72 *$ & $3.15 *$ & $22.09^{*}$ & $-3.07 *$ & $14.97 *$ \\
\hline $175-190$ & $-4.85^{*}$ & $-19.91 *$ & $5.90 *$ & $30.84 *$ & $2.55^{*}$ & $19.24 *$ & -0.60 & -1.81 \\
\hline $191-205$ & -6.43 & $-18.10 *$ & $5.68 *$ & $19.42 *$ & $6.49 *$ & $27.76^{*}$ & $-5.29 *$ & $12.00 *$ \\
\hline $206-221$ & 1.60 & $9.84 *$ & $3.11 *$ & $9.38 *$ & $4.71 *$ & $26.06^{*}$ & -0.19 & $-12.15^{*}$ \\
\hline $222-236$ & $2.61 *$ & $23.61 *$ & $3.53 *$ & $24.86^{*}$ & $6.02 *$ & $39.29 *$ & -0.07 & $-3.55^{*}$ \\
\hline $237-240$ & $5.64 *$ & $23.43 *$ & $4.23 *$ & $17.70 *$ & $7.55 *$ & $-21.21 *$ & $-6.54 *$ & $-20.84 *$ \\
\hline Overall means & - & - & - & - & - & - & - & - \\
\hline
\end{tabular}

\footnotetext{
* Refers to the age groups showing significant differences $(\mathrm{p}<0.05)$
} 
The average number of eggs per egg-mass in both species raised in groups was 14.5 for B. glabrata and 12.9 for B. straminea. There was a significant difference $(\mathrm{p}<0.05)$ between the species in almost all age groups. B. straminea had average number of eggs per egg-mass equal to or higher than B. glabrata, and from the 191 - 205 age group onwards, this behavior was reversed (Table 2).

The average number of eggs per egg-mass was 4.6 and 12.3 for $B$. glabrata and $B$. straminea, respectively, in both species raised individually (Table 2). The average number of eggs per egg-mass for $B$. straminea was always higher than that for B. glabrata all age groups. Comparing the average figures for the number of eggs per egg-mass between the species shows a significant difference $(\mathrm{p}<0.05)$ in all age groups.

The comparison of $B$. glabrata between both types of breeding conditions showed a significant difference $(\mathrm{p}<0.05)$ for almost all age groups, with an average number of egg-masses per snail of 2.8 for the groups and 1.0 for those raised individually. We also found an average number of eggs per snail of 54.3 in the groups and 8.1 for the individually raised (Table 1).

The average number of eggs per egg-mass was always higher for $B$. glabrata in groups than for the individuals at all age groups studied. We found an average number of eggs per egg-mass of 14.5 and 4.6 for $B$. glabrata raised in groups and individually, respectively. With the exception of the 99-113 day age group under both breeding conditions, significant differences were noted $(\mathrm{p}<0.05)$ in all the other age groups, favoring B. glabrata in groups (Table 2).

A comparison of the results for $B$. straminea given in Table 1 by age group shows that there was little difference in the average number of egg-masses per snail between B. straminea raised in groups and individually, at 3.8 and 4.1 respectively. A significant difference $(\mathrm{p}<$ 0.05 ) in the $114-129,160-174,191-205$ and 237 - 240 day age groups. No significant difference was noted for the other age groups. The average number of eggs per snail of 71.7 and 64.4 raised in groups and individually showed a significant difference $(\mathrm{p}<0.05)$ in almost all age groups.

The average number of eggs per egg-mass was 12.9 for $B$. straminea raised in groups and 12.3 when raised individually. In general, there was little difference between the two breeding conditions at the different age groups. A significant difference $(\mathrm{p}<0.05)$ was noted between $B$. straminea raised in groups and individually in the 130 - 144, 145 - 159, 206 - 221 and 237 - 240 day age groups (Table 2).

\section{FERTILITY}

Hatch rate comparison: The average hatch rates obtained were $64.6 \%$ and $63.1 \%$ for B. glabrata and B. straminea respectively in groups, with a significant difference $(\mathrm{p}<0.05)$ noted for $B$. straminea in all age groups except the 99 - 113 and 114-129 day groups (Table 3).

A hatch rate of $57.2 \%$ was observed for B. glabrata and $70.7 \%$ for $B$. straminea raised individually. The comparison of the hatch rate between the species by age group indicated a significant difference $(\mathrm{p}<$ 0.05 ) in almost all age groups, the exceptions being 114 - 129, 130 144, 206 - 240 and 237 - 240 days (Table 3).

A hatch rate of $64.6 \%$ for B. glabrata raised in groups and $57.2 \%$ for those raised individually was noted, with significant differences in almost all age groups (Table 3).

Table 2

Number of eggs per egg-mass (mean) laid by Biomphalaria glabrata and Biomphalaria straminea raised in groups and individually, by age group

\begin{tabular}{|c|c|c|c|c|c|c|c|c|}
\hline \multirow{3}{*}{$\begin{array}{l}\text { Age group } \\
\text { (days) }\end{array}$} & \multirow{2}{*}{\multicolumn{2}{|c|}{$\begin{array}{c}\text { Eggs/egg-masses } \\
\text { B. glabrata }\end{array}$}} & \multirow{2}{*}{\multicolumn{2}{|c|}{$\begin{array}{c}\text { Eggs/egg-masses } \\
\text { B. straminea }\end{array}$}} & \multicolumn{4}{|c|}{ Eggs/egg-masses } \\
\hline & & & & & \multirow{2}{*}{$\begin{array}{c}\text { Test "t" } \\
\text { B. glabrata X } \\
\text { B. straminea } \\
\text { (Group) }\end{array}$} & \multirow{2}{*}{$\begin{array}{l}\text { Test "t" } \\
\text { B. glabrata X } \\
\text { B. straminea } \\
\text { (Individual) }\end{array}$} & \multirow{2}{*}{$\begin{array}{l}\text { Test "t" } \\
\text { B. glabrata } \\
\text { Group X } \\
\text { Individual }\end{array}$} & \multirow{2}{*}{$\begin{array}{l}\text { Test " } \mathrm{t} \text { " } \\
\text { B. straminea } \\
\text { Group X } \\
\text { Individual }\end{array}$} \\
\hline & Group & Individual & Group & Individual & & & & \\
\hline $0-83$ & 0.0 & 0.0 & 0.0 & 0.0 & - & - & - & - \\
\hline $84-98$ & 0.0 & 0.0 & 7.2 & 3.6 & $-4.17 *$ & $-11.54 *$ & - & 2.00 \\
\hline $99-113$ & 10.0 & 7.5 & 11.9 & 14.2 & -0.92 & -1.83 & 1.00 & -1.77 \\
\hline $114-129$ & 15.2 & 10.9 & 13.6 & 16.3 & 1.01 & $-3.42 *$ & $2.52 *$ & -1.96 \\
\hline $130-144$ & 16.2 & 7.0 & 18.8 & 16.0 & $-2.25^{*}$ & $-4.07 *$ & $4.56^{*}$ & $2.35 *$ \\
\hline $145-159$ & 14.2 & 9.0 & 18.4 & 15.3 & $-4.09 *$ & $-3.86^{*}$ & $3.73 *$ & $2.67 *$ \\
\hline $160-174$ & 15.6 & 7.5 & 19.8 & 18.8 & $-3.63 *$ & $-7.19 *$ & $4.05 *$ & 0.76 \\
\hline $175-190$ & 18.2 & 4.1 & 17.5 & 17.0 & 0.43 & $-5.21 *$ & $4.97 *$ & 0.31 \\
\hline $191-205$ & 18.2 & 0.0 & 13.2 & 11.2 & $5.36^{*}$ & $-8.73^{*}$ & $10.10 *$ & 1.45 \\
\hline $206-221$ & 21.5 & 3.0 & 19.0 & 5.7 & 1.09 & $-1.17 *$ & $3.79 *$ & $4.76 *$ \\
\hline $222-236$ & 27.8 & 2.0 & 16.4 & 20.0 & $6.05 *$ & $-6.76^{*}$ & $7.80 *$ & -1.70 \\
\hline $237-240$ & 17.2 & 4.1 & 0.0 & 10.1 & $10.71 *$ & $-3.51 *$ & $5.76^{*}$ & $-8.45^{*}$ \\
\hline Overall mean & 14.5 & 4.6 & 12.9 & 12.3 & - & - & - & - \\
\hline
\end{tabular}

* Refers to the age groups showing significant differences $(\mathrm{p}<0.05)$ 


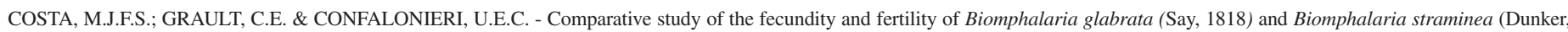
1848) in a laboratory through self-fertilization and cross-fertilization. Rev. Inst. Med. trop. S. Paulo, 46(3):157-163, 2004.

Table 3

Hatch rate $(\%)$ : ratio between the number of snails hatched and number of fertile eggs and percentage of fertile eggs studied individually and in groups for $B$. glabrata and B. straminea, according to age group

\begin{tabular}{|c|c|c|c|c|c|c|c|c|}
\hline $\begin{array}{l}\text { Age group } \\
\text { (days) }\end{array}$ & $\begin{array}{c}\text { Hatch rate }(\%) \\
\text { Group }\end{array}$ & $\begin{array}{l}\text { B. glabrata } \\
\text { Individual }\end{array}$ & $\begin{array}{l}\text { Hatch rate }(\%) \\
\text { Group }\end{array}$ & $\begin{array}{l}\text { B. straminea } \\
\text { Individual }\end{array}$ & $\begin{array}{c}\% \text { of fertile eggs } \\
\text { Group }\end{array}$ & $\begin{array}{l}\text { B. glabrata } \\
\text { Individual }\end{array}$ & $\begin{array}{c}\% \text { of fertile eggs } \\
\text { Group }\end{array}$ & $\begin{array}{l}\text { B. straminea } \\
\text { Individual }\end{array}$ \\
\hline $0-83$ & 0.0 & 0.0 & 0.0 & 0.0 & 0.0 & 0.0 & 0.0 & 0.0 \\
\hline $84-98$ & 0.0 & 0.0 & 87.1 & 96.6 & - & 0.0 & 53.4 & 100.0 \\
\hline $99-113$ & 87.8 & 93.3 & 82.8 & 71.8 & 92.1 & 100.0 & 91.4 & 95.7 \\
\hline $114-129$ & 75.4 & 82.3 & 79.8 & 86.7 & 94.9 & 98.9 & 95.6 & 98.5 \\
\hline $130-144$ & 76.9 & 65.2 & 73.0 & 68.6 & 94.1 & 97.8 & 98.0 & 98.1 \\
\hline $145-159$ & 88.9 & 89.9 & 69.3 & 83.2 & 98.2 & 93.3 & 96.6 & 98.1 \\
\hline $160-174$ & 83.7 & 94.6 & 79.8 & 76.5 & 97.4 & 91.8 & 98.4 & 98.9 \\
\hline $175-190$ & 75.6 & 48.9 & 77.9 & 87.9 & 97.7 & 94.0 & 97.7 & 98.7 \\
\hline $191-205$ & 78.5 & 0.0 & 64.4 & 80.2 & 97.1 & 0.0 & 98.3 & 96.7 \\
\hline $206-221$ & 79.5 & 83.3 & 60.6 & 97.3 & 97.4 & 80.0 & 96.2 & 81.5 \\
\hline $222-236$ & 76.6 & 59.3 & 83.4 & 92.6 & 97.6 & 90.0 & 95.5 & 97.2 \\
\hline $237-240$ & 53.4 & 70.3 & 0.0 & 70.6 & 95.0 & 90.2 & 0.0 & 95.1 \\
\hline Overall means & 64.6 & 57.2 & 63.1 & 70.7 & 80.1 & 70.0 & 76.7 & 88.2 \\
\hline
\end{tabular}

\begin{tabular}{|c|c|c|c|c|c|c|}
\hline \multirow[b]{2}{*}{$\begin{array}{l}\text { Age group } \\
\text { (days) }\end{array}$} & \multicolumn{4}{|c|}{ Hatch rate $(\%)$} & \multicolumn{2}{|c|}{$\%$ of fertile eggs } \\
\hline & $\begin{array}{c}\text { Test " } \mathrm{t} " \\
\text { B. glabrata X } \\
\text { B. straminea } \\
\text { (Group) }\end{array}$ & $\begin{array}{c}\text { Test " "t" } \\
\text { B. glabrata X } \\
\text { B. straminea } \\
\text { (Individual) }\end{array}$ & $\begin{array}{c}\text { Test " } \mathrm{t} " \\
\text { B. glabrata } \\
\text { Group X } \\
\text { Individual }\end{array}$ & $\begin{array}{l}\text { Test "t" } \\
\text { B. straminea } \\
\text { Group X } \\
\text { Individual }\end{array}$ & $\begin{array}{c}\text { Test " } \mathrm{t} " \\
\text { B. glabrata X } \\
\text { B. straminea } \\
\text { (Group) }\end{array}$ & $\begin{array}{c}\text { Test "t" } \\
\text { B. glabrata X } \\
\text { B. straminea } \\
\text { (Individual) }\end{array}$ \\
\hline $0-83$ & - & - & - & - & - & - \\
\hline $84-98$ & - & - & - & -1.09 & - & - \\
\hline $99-113$ & -1.45 & $4.07 *$ & -1.03 & $3.28 *$ & 0.27 & $3.67 *$ \\
\hline $114-129$ & -1.69 & -1.89 & $-2.34 *$ & $-3.67 *$ & -0.54 & 0.58 \\
\hline $130-144$ & $2.52 *$ & -0.65 & $2.25^{*}$ & $2.38 *$ & $-5.29 *$ & -0.19 \\
\hline $145-159$ & $13.63^{*}$ & $2.99 *$ & -0.48 & $-8.59 *$ & 2.81 & $-2.91 *$ \\
\hline $160-174$ & $3.61 *$ & $8.67 *$ & $-5.44 *$ & $2.58 *$ & -2.27 & $-3.46 *$ \\
\hline $175-190$ & $-2.93 *$ & $-9.29 *$ & $3.61 *$ & $-7.16^{*}$ & 0.0 & -1.39 \\
\hline $191-205$ & $9.45^{*}$ & $-34.45 *$ & - & $-6.25^{*}$ & $-2.30 *$ & - \\
\hline $206-221$ & $8.94 *$ & -1.28 & -0.39 & $-14.20 *$ & 1.47 & -0.14 \\
\hline $222-236$ & $-3.81 *$ & $-3.49 *$ & 1.82 & $-4.64 *$ & $2.30 *$ & -1.30 \\
\hline $237-240$ & 0.0 & -0.04 & $2.20 *$ & - & - & -1.02 \\
\hline Overall means & - & - & - & - & - & - \\
\hline
\end{tabular}

* Refers to age groups showing significant differences $(\mathrm{p}<0.05)$

B. straminea had a mean hatch rate of $63.1 \%$ for the snails raised in groups and $70.7 \%$ for the individuals, a significant difference $(\mathrm{p}<0.05)$ in all age groups with the exception of 84 - 98 days (Table 3).

Percentage of fertile eggs: We observed mean percentages of fertile eggs of $80.1 \%$ and $76.7 \%$ for B. glabrata and B. straminea raised in groups, respectively (Table 3 ). When the snails were raised individually, we found mean percentages of fertile eggs of $70.0 \%$ for B. glabrata and $88.2 \%$ for $B$. straminea. The comparison between the two species raised as groups and individuals indicated significant differences only in some age groups. The same occurred when intra-specific comparisons were carried out, implying that there would be no marked differences between them when raised in groups or individually. Although there were significant differences in the percentages of fertile eggs between the two species in the $130-144,145-159,160-174,191-205$ and $222-236$ day ages raised in groups and 99 - 113, 145 -159 and 160 - 174 days raised individually Table 3 shows that the percentage of fertile eggs for these two species was very similar.

\section{DISCUSSION}

\section{FECUNDITY}

Number of egg-capsules per snail: Laboratory studies of the fecundity of the $B$. glabrata present highly variable figures for the average number of egg-masses per snail. Studying this same species, BRUMPT ${ }^{11}$ found 0.89 for individuals and 0.76 for paired snails, while REY ${ }^{24}$ obtained 5.2 and 3.1 egg-masses per snail for individuals and 6.4 and 4.8 for grouped snails, assigning higher rates to snails with larger 


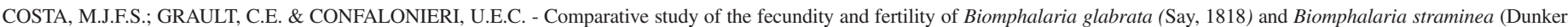
1848) in a laboratory through self-fertilization and cross-fertilization. Rev. Inst. Med. trop. S. Paulo, 46(3):157-163, 2004.

diameters. SZUMLEWICZ ${ }^{23}$ obtained an average of 0.47 and 0.67 eggmasses per snail for the pairs and individual snails respectively, while RITCHIE et al. ${ }^{25}$ obtained different results, observing a higher number of egg-masses per snail when raised in pairs (1.7 egg-masses per snail) instead of keeping them separate ( 0.6 egg-masses per snail) or raised in groups (1.4 egg-masses per snail). BARRETO ${ }^{10}$ observed 2.6 and 2.9 for the groups and 1.0 and 2.2 for the individuals. MAGALHÃES \& CARVALHO ${ }^{17}$ observed an average of 9.6 egg-masses per snail for the pairs over a period of 30 days, while $\mathrm{KAWAZOE}^{16}$ noted an average of 12.8 over 20 days, also for the pairs.

In the course of this study, we noted through weekly observations that $B$. glabrata raised separately showed a drop in egg-mass production as the sample aged. The significant difference in the number of eggmasses per snail for cross-fertilization, compared to self-fertilization suggests that for B. glabrata, cross-fertilization remains preferential, confirming most of the data in the literature ${ }^{10,24,25}$.

For $B$. straminea, the average observed was 3.8 egg-masses per snail for the groups and 4.1 for the individuals. These findings indicate that the reproductive capacity of $B$. straminea does not drop either in groups or individually, although mention is made in the literature of the preference for cross-fertilization among the planorbids ${ }^{20}$.

Comparing B. glabrata with B. straminea individually, we also found a higher average for $B$. straminea, with 4.1 egg-masses per snail and 1.0 for B. glabrata. B. straminea was more fecund than B. glabrata throughout the entire period under study, favoring this species.

ROZEMBERG et al. ${ }^{26}$ studied cross-fertilization over a 12-month period, finding an average of 0.9 egg-masses per snail for $B$. straminea and 0.69 for $B$. glabrata. In this study, larger numbers of egg-masses per snail were also noted for $B$. straminea. In general, $B$. straminea produced a larger number of egg-masses than B. glabrata, with its reproduction peaking during the 160-174 age group (Table 1).

Number of eggs per egg-mass: The earliest laboratory studies on the number of eggs per egg-mass were carried out by BRUMPT ${ }^{11}$, obtaining 23.3 eggs per egg-mass for self-fertilization. REY ${ }^{24}$ compared B. glabrata raised in groups and individually, finding 10.2 and 16.9 eggs per egg-mass and 10.9 and 18.2 eggs per egg-mass respectively. In this study, an average of 14.5 eggs per egg-mass was found for the groups and 4.6 eggs per egg-mass for the individuals, indicating the advantage of B. glabrata in cross-fertilization. The results found in this study for the individuals are close to those of BARRETO ${ }^{10}$, who obtained an average of 5.3 and 4.7 eggs per egg-mass for the individuals and far higher averages for the group, at 7.4 and 7.5 eggs per egg-mass. In this study, the superiority of $B$. glabrata raised in groups is easily noted. The phenomenon of self-fertilization was found more widely in younger animals when compared to B. glabrata raised in groups.

We obtained averages for B. straminea of 12.9 and 12.3 eggs per eggmass for both the groups and the individuals. The analysis in Table 2 shows that in general, B. straminea raised in groups and individually behaved similarly, with the exception of the 237 - 240 day age group, when no eggmasses where laid. As also noted in the eggs per snail ratio, $B$. straminea seems to undergo no alterations in terms of the production of egg-masses or eggs, indicating the high reproductive efficiency of this species.
Regarding comparison between eggs per egg-mass, JANSEN ${ }^{15}$ carried out the first studies in populations of B. glabrata and B. straminea. He found an average of 12.0 eggs per egg-mass for $B$. straminea and 45.0 for $B$. glabrata. PENIDO et al. $^{22}$ studied the same species and noted averages of 13.2 and 24.5 eggs per egg-mass respectively. ROZEMBERG et al. ${ }^{26}$ noted an average of 22.4 eggs per egg-mass for B. straminea and 13.08 eggs per egg-mass for B. glabrata. We found 14.5 eggs per eggmass for $B$. glabrata and 12.9 eggs per egg-mass for $B$. straminea, in keeping with the first two authors.

According to ROZEMBERG et $a l .{ }^{26}$, her results may be due to the fact that the population of $B$. straminea at Picos (Piauí State) used in her experiment was more fertile than those in other $B$. straminea species raised in the laboratory under the same conditions. There were significant differences between B. glabrata and B. straminea raised individually, for almost all age groups, with an average of 4.6 for $B$. glabrata and 12.3 for $B$. straminea eggs per egg-mass, favoring $B$. straminea considerably with regard to self-fertilization. The production of eggmasses is not necessarily related to the production of eggs, and the reproductive superiority of $B$. straminea is largely due to a high production of eggs in a relatively small number of egg-masses, meaning that egg-laying activity is more efficiently exploited by this species for effective production of descendants.

Number of eggs per snail: Using a group of $B$. glabrata and varying the water volume, $\mathrm{REY}^{24}$ found an average of 326.3 and 168.1 for the groups, and 24.6 and 87.6 for the individuals, which are relatively high averages. Raising snails in groups and individually, BARRETO ${ }^{10}$ obtained an average of 47.0 and 42.0 eggs per snail for the groups and 18.1 and 33.0 eggs per snail for the individuals. Under individual conditions, RITCHIE et al. ${ }^{25}$ obtained 23.0 eggs per snail for individuals and 66.0 eggs per snail for the groups over a period of eight months. The findings in this paper are quite consistent with those noted above.

Few data are available in the literature on B. straminea egg production. Table 1 presents the variation in the number of eggs per snail for B. straminea in groups and individually, showing that there was little variation in the number of eggs per snail, while in some age groups, $B$. straminea performed better as individuals than in groups. It seems that self-fertilization is not a limiting factor for this species, in terms of reproductive capacity.

Comparing the number of eggs per snail, between the B. glabrata and $B$. straminea species raised in groups, ROZEMBERG et al. ${ }^{26}$ observed an average of 10.1 eggs per snail for B. glabrata and 23.9 eggs per snail for $B$. straminea over a period of one year. We found averages of 71.7 and 54.3 eggs per snail for B. straminea and B. glabrata respectively, in keeping with the observations of the above author (Table $1)$.

Looking at the two species raised individually, the superiority of $B$. straminea was quite clear compared to B. glabrata, for all age groups studied (Table 1).

These results confirm previous studies in laboratories by MICHELSON \& DUBOIS ${ }^{19}$, where $B$. straminea was found to be more fecund than B. glabrata. B. straminea has some specific characteristics, such as vagility, aggressiveness, resistance to desiccation, high rate of 


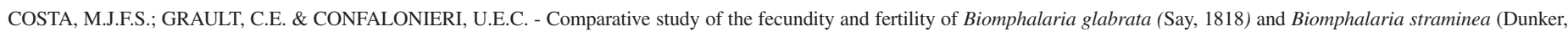
1848) in a laboratory through self-fertilization and cross-fertilization. Rev. Inst. Med. trop. S. Paulo, 46(3):157-163, 2004.

locomotion and power of exploration, and great adaptability to environmental conditions ${ }^{4,5,6}$. Hence, all these characteristics are important if we relate them with the greater fecundity of $B$. straminea, explaining its greater success in the face of adverse factors. This being the case, self-fertilization is extremely favorable for the transmission of schistosomiasis, since it only takes a single individual in different types of biotopes to ensure the population density and prevalence, particularly in Northeast Brazil.

\section{FERTILITY}

Hatch rate: Looking at the hatch rate for planorbids belonging to the Biomphalaria genus raised in groups, BRUMPT ${ }^{11}$ noted rates of 85 $100 \%$. In this paper, a hatch rate of $64.6 \%$ for B. glabrata in groups and $57.2 \%$ for the individuals was observed. Table 3 shows that significant differences were observed only for some age groups, without preference for individual or group. On the other hand, PARAENSE ${ }^{20}$ found a hatch rate of $78.3 \%$ for B. glabrata in egg-masses obtained through selffertilization. BARRETO ${ }^{10}$ found hatch rates of $64 \%$ and $43 \%$ for individuals and $78.8 \%$ and $83.0 \%$ for the groups. The results obtained by that author are close to those found for the individual B. glabrata. The lowest hatch rate found in our project was $53.4 \%$ for the groups. These results are in accordance with those of $\mathrm{REY}^{24}$, who noted a wide variation in egg fertility, depending on the batches used and the time of year. He observed a hatch rate for B. glabrata that ranged from $37.7 \%$ to $56.0 \%$.

$\mathrm{KAWAZOE}^{16}$ found an average of $95.8 \%$ for B. glabrata in pairs and MAGALHÃES \& LUCCA ${ }^{18}$ obtained a rate of $91.6 \%$ for $B$. glabrata in groups. In this paper, the hatch rates for B. glabrata in groups and individually show significant differences for some age groups, with a significant drop in the hatch rate for the groups is the last age group (Table 3). Whether raised in groups or individually, B.straminea showed variations in the average figures for all age groups studied. An overall average of $63.1 \%$ was obtained for the groups and $70.7 \%$ for the individuals, showing a significant difference for almost all age groups.

The overall average for the B. glabrata and B. straminea groups was $64.6 \%$ and $63.1 \%$ respectively. Table 3 shows certain variations in some age groups. Comparing $B$. glabrata with $B$. straminea raised individually, the same variations are noted. The overall average for the hatch rate was $57.2 \%$ for B. glabrata and $70.7 \%$ for B. straminea. The fertility rate for the two species seems to show that there are no age groups that are more successful at hatching.

Percentage of fertile eggs: BRUMPT ${ }^{11}$ noted that certain egg-masses deposited by animals raised individually did not develop at all, retaining the same appearance several weeks later as when first laid. Otherwise, these sterile egg-masses seemed no different from the normal eggcapsules, and occurred at any time in the reproductive life of the snails, being interspersed with fertile laying activities. REY ${ }^{24}$ found sterile eggs in fertile egg-capsules, although always at a very low rate, varying from zero to $2.7 \%$ for B. glabrata.

In this study, the percentage of fertile eggs recorded range from $92.1 \%$ to $98.2 \%$ for the B. glabrata groups, while the individuals varied from $80.0 \%$ to $100 \%$. We found $53.4 \%$ to $98.4 \%$ for the B. straminea raised in groups and $81.5 \%$ to $100 \%$ for the individuals. The parameters studied for the two species presented little significant difference between the age groups. Consequently, there seems to be no trend for better periods to produce fertile eggs.

\section{CONCLUSION}

It was observed that $B$. straminea showed greater reproductive potential than B. glabrata, both when kept in groups and isolated. A comparison of the rates of intraspecific fecundity (average number of egg-masses/snail, eggs/snail and eggs/egg mass) suggests that selffertilization as a reproductive strategy is more efficient in B. straminea, since the values found are very near those observed in the group snails. The fertility of the two species was relatively high, with no significant differences between them. This being the case, relating these observations with actions taken to control the intermediate hosts of $S$. mansoni points to the need for better follow-up of these measures not only based on seasonal climatic variations and transmission, but also fundamentally on studies of the population dynamics of each of the target species. Further studies are warranted, including with different samples of both species, to investigate other aspects of the fecundity and reproductive behavior that may be involved in competition for the space available and the occupation of new ecotopes.

\section{RESUMO}

\section{Estudo comparativo da fecundidade e fertilidade de Biomphalaria glabrata (Say, 1818) e Biomphalaria straminea (Dunker, 1848) em laboratório por autofecundação e fecundação cruzada}

O objetivo deste trabalho foi comparar a fecundidade e fertilidade de Biomphalaria glabrata e Biomphalaria straminea em condições de laboratório considerando a autofecundação e a fecundação cruzada. Durante oito meses, foram registrados em laboratório, o número de cápsulas ovíferas (desovas), ovos por cápsula ovífera, ovos totais, taxa de eclosão e percentual de ovos férteis dos moluscos criados individualmente e agrupados. Foram utilizados exemplares de $B$. glabrata de Paulista, PE e B. straminea oriunda de Petrolândia, PE. As observações foram divididas por faixa etária no periódo de 0 a 240 dias. Os resultados obtidos neste trabalho mostram que $B$. straminea apresenta um potencial reprodutivo maior do que $B$. glabrata, tanto para moluscos criados em grupo quanto para os criados individualmentes. A comparação dos valores encontrados para fecundidade dentro da mesma espécie sugere que a autofecundação como estratégia reprodutiva, é mais eficiente em $B$. straminea, já que as médias encontradas (número médio de capsúlas ovíferas e ovos por cápsula ovífera) são bem próximos aos valores observados nos moluscos mantidos em grupo. Com relação à fertilidade, parece não existir períodos favoráveis para a eclosão, não havendo também um ritmo e nenhuma tendência para a produção de ovos férteis.

\section{ACKNOWLEDGEMENTS}

The authors are grateful to Dr. Constância Simões Barbosa of the Aggeu Magalhães Research Center, Recife, Pernambuco, Fiocruz, for the snails kindly allocated to this project, and to Dr. Frederico Simões Barbosa (in memorian) for his suggestions and comments, as well as to Prof. Takumi Iguchi of ENSP/FIOCRUZ for statistical support. This study is part of the M. Sc. Thesis of the first author. 


\section{REFERENCES}

1. ANDRADE, R.M.; CARVALHO, O.S. \& MENEZES, W.T. - Alimentação e fecundidade de planorbídeos criados em laboratório. III. Biomphalaria glabrata (Say, 1818) (Pulmonata, Planorbidae). Rev. bras. Malar., 26: 109-129, 1974.

2. ANDRADE, R.M.; CARVALHO, O.S. \& PINTO ALVES, M.D.P. - Alimentação e fecundidade de planorbídeos criados em laboratório. II. Biomphalaria straminea (Dunker, 1848). Rev. bras. Biol., 33: 119-126, 1973.

3. BARBOSA, F.S. - Possible competitive displacement and evidence of hybridization between two Brazilian species of planorbid snails. Malacologia, 14: 401-408, 1973.

4. BARBOSA, F.S.; PEREIRA DA COSTA, D.P. \& ARRUDA, F. - New field observations on the competitive displacement between two species of planorbid snails inhabiting northeastern Brazil. Mem. Inst. Oswaldo Cruz, 76: 361-366, 1981.

5. BARBOSA, F.S.; PEREIRA DA COSTA, D.P. \& ARRUDA, F. - Competitive interactions between species of freshwater snails. I. Laboratory: Ia. General methodology. Mem. Inst. Oswaldo Cruz, 78: 335-341, 1983.

6. BARBOSA, F.S.; PEREIRA DA COSTA, D.P. \& ARRUDA, F. - Competitive interactions between species of freshwater snails. I. Laboratory studies: Ib. Comparative studies of the dispersal and the vagility capabilities of Biomphalaria glabrata and Biomphalaria straminea. Mem. Inst. Oswaldo Cruz, 79: 163-167, 1984.

7. BARBOSA, F.S.; PEREIRA DA COSTA, D.P. \& ARRUDA, F. - Competitive interactions between species of fresh-water snails. I. Laboratory. IC. Comparative survival of Biomphalaria glabrata and B. straminea kept out of water. Mem. Inst. Oswaldo Cruz, 80: 155-157, 1985.

8. BARBOSA, F.S. - Competitive displacement of Biomphalaria glabrata by Biomphalaria straminea. Mem. Inst. Oswaldo Cruz, 82 (suppl. 4): 139-141, 1987.

9. BARBOSA, F.S.; SANCHES, O.; BARBOSA, C.S. \& ARRUDA, F. - Dynamics of snail populations of Biomphalaria glabrata and Biomphalaria straminea under semi-natural conditions. Cadern. Saúde públ. (Rio de J.), 8: 157-167, 1992.

10. BARRETO, A.C. - Esquistossomose mansônica na cidade de Salvador. Estudo do vetor, relação parasito-hospedeiro e aspectos epidemiológicos. Bol. Fund. G. Moniz, 16: 1-80, 1960.

11. BRUMPT, E. - Observations biologiques diverses concernent Planorbis (Australorbis) glabratus, hôte intermediaire de Schistosoma mansoni. Ann. Parasit. hum. comp., 18: 9-45, 1941.

12. COSTA, M.J.F.S. - Estudo comparativo da fecundidade e fertilidade de Biomphalaria glabrata (Say, 1818) e Biomphalaria staminea (Dunker, 1848) em laboratório. Rio de Janeiro, 1995. (Dissertação de mestrado - Universidade Federal Rural do Rio de Janeiro).

13. FOWLER, J. \& COHEN, L. - Practical statistics for field biology. Buckhingham, Open University Press, 1990.
14. JANNOTTI-PASSOS, L.K. \& SOUZA, C.P. - Susceptibility of Biomphalaria tenagophila and Biomphalaria straminea to Schistosoma mansoni infection detected by low stringency polymerase chain reaction. Rev. Inst. Med. trop. S. Paulo, 42: 291-294, 2000 .

15. JANSEN, G. - Sobre a validade de Australorbis centimetralis (Lutz, 1918). Mem. Inst. Oswaldo Cruz, 40: 201-208, 1944.

16. KAWAZOE, U. - Alguns aspectos da biologia de Biomphalaria glabrata (Say, 1818) e Biomphalaria tenagophila (D’Orbigny, 1835) (Pulmonata, Planorbidae). II. Fecundidade e fertilidade. Rev. Saúde públ. (S. Paulo), 11: 47-64, 1977.

17. MAGALHÃES, L.A. \& CARVALHO, J.F. - Estudo da postura de duas populações de planorbídeos. Rev. Soc. bras. Med. trop., 3: 245-248, 1969.

18. MAGALHÃES, L.A. \& LUCCA, O. - Determinação do período de desenvolvimento e da viabilidade das desovas de duas populações de B. glabrata e de B. tenagophila (Mollusca, Planorbidae). Rev. Soc. bras. Med. trop., 5: 307-313, 1971.

19. MICHELSON, E.H. \& DUBOIS, L. - Competitive interaction between two snail hosts of Schistosoma mansoni: laboratory studies on Biomphalaria glabrata and Biomphalaria straminea. Rev. Inst. Med. trop. S. Paulo, 21: 246-253, 1979.

20. PARAENSE, W.L. - Autofecundação e fecundação cruzada em Australorbis glabratus. Mem. Inst. Oswaldo Cruz, 53: 277-291, 1955.

21. PARAENSE, W.L. \& CORRÊA, L.R. - Self-fertilization in freshwater snail Helisoma duryi and Helisoma trivolvis. Mem. Inst. Oswaldo Cruz, 83: 405-409, 1988.

22. PENIDO, H.M.; PINTO, D.B. \& DESLANDES, N. - Observações sobre as posturas e tempo de ovulação de duas espécies de caramujos encontrados no Vale do Rio Doce. Rev. Serv. Saúde públ., 4: 407-412, 1951.

23. SZUMLEWICZ, A.P. - Studies on the biology of Australorbis glabratus, schistosome bearing Brazilian snail. Rev. bras. Malar., 10: 459-529, 1958.

24. REY, L. - Contribuição para o conhecimento da morfologia, biologia e ecologia dos planorbídeos transmissores de esquistossomose. Sua importância em epidemiologia. São Paulo, 1956. (Tese de Doutorado - Faculdade de Medicina da Universidade de São Paulo).

25. RITCHIE, L.S.; HERNANDEZ, A. \& ROSA AMADOR, R. - Biological potentials of $A$ glabratus. Life span and reproduction. Amer. J. trop. Med. Hyg., 15: 614-617, 1966.

26. ROZEMBERG, B.; REY, L. \& PIERI, O.S. - Fecundity of Biomphalaria straminea and B. glabrata in the laboratory: a twelve-month comparative study. Mem. Inst. Oswaldo Cruz, 87 (suppl. 1): 223-232, 1992.

27. SOUZA, C.P.; CUNHA, R.C.P. \& ANDRADE, Z.A. - Development of Schistosoma mansoni in Biomphalaria tenagophila, Biomphalaria straminea and Biomphalaria glabrata. Rev. Inst. Med. trop. S. Paulo, 37: 201-206, 1995.

Received: 3 November 2003

Accepted: 12 May 2004 